\title{
The Effectiveness of the Equality Dynamic Learning Model in Increasing Disability Awareness of Students in Inclusion Classes
}

\author{
${ }^{1}$ Yulvia Sani, ${ }^{2}$ Ossy Firstanti Wardany, ${ }^{3}$ Genesa Vernanda, ${ }^{4}$ Heni Herlina \\ 1,2,3,4 Special Needs Education Department, Universityy of Muhammadiyah Lampung, Bandar Lampung, Indonesia
}

\begin{abstract}
The background of the research is the low acceptance problem of the presence of a student with disabilities caused by the lack of disability awareness. Found several problems from the regular students to a student with disabilities, i.e some students indicate a rejection to every work-group with him. Based on the problems, this research provides a model, named "Equality Dynamic Learning (EDL)". The EDL model conceptualizes "dynamic learning that creates equal rights in learning", it means that learning activities are designed in such a way that takes into account the diversity that is owned by students (students with special and regular needs) and accommodates all these needs in learning activities so that all students in the class have meaningful learning. The subjects in this study were 19 students, 1 student with special needs with physical disabilities (Hamid (H), 18 y.o). The research methodology in this study is a quasi-experimental design with one group pretest-posttest without control class. The results of the study showed that the condition of pretest disability awareness of students in the moderate category was $63 \%$; the high category was $37 \%$. The condition of posttest of disability awareness for high category students was $16 \%$; very high category was $84 \%$. The disability awareness condition experienced a significant increase after the dynamic learning equality model was given to students in the inclusive class. Wilcoxon calculations were performed with the result that in the asymp sig (2-tailed) column to be tested 2 sides were 0,000 . Because the case is a one-tailed test, the probability becomes $0,000 / 2=0,000$. Here the probability is below 0.05 . So, based on the results of this study, The EDL model is effective in increasing the disability awareness of students in inclusive classroom.
\end{abstract}

Keywords: Equality Dynamic Learning Model, Disability Awareness, Inclusive Class

\section{Research Background}

Education aimed to educate and develop the potential of every student. Every Indonesian citizen has the right to get education in accordance with the 1945 Constitution article 31 paragraph 1 . Indonesia requires every citizen to have education for nine years. Educated people will determine in what direction the future of the nation. Education can not only be obtained by normal children or children in general, but children with special needs also have the same rights.

\footnotetext{
* Corresponding author: Yulvia Sani

email: yulviasani@yahoo.co.id

Published online at http://IJDS.ub.ac.id

Copyright $\odot 2020$ PSLD UB Publishing. All Rights Reserved
}

Children with special needs are children who have different needs and services from children in general. Different needs and services because educational services provided to children with special needs are often separated from children in general. Educational services that accept children with special needs are often known by people as SLB (Segregrated School).

Beside segregated educational system that put students with special needs aside of mainstream educational context, another promising alternative for facilitating students with special needs is inclusive education, where they learn along with the students without disabilities in the mainstream educational 
context. Inclusive education does not merely combine children with special needs with children in general. Many things must be considered in inclusive education, ranging from school accessibility, Teacher competence on handling children with special needs, socialization of children with special needs to the school environment, the accessible admission system", and so on.

At this time the Muhammadiyah Lampung University has begun to implement Inclusive education services for disability inclusion. Nevertheless, the effort of implementing the inclusive education remains challenging.

In a class, there is one student with special needs who initials " $\mathrm{H}$ ". He is a student with physical and motor impairments in the hands. In this class, there seems to be low acceptance of students with special needs. Low acceptance is due to lack of disability awareness which can be caused by low social contact and less understanding about him. Lack of acceptance can be seen from the reactions of other students when learning. For example, when there is group learning, there are rarely other students who directly propose themselves to a group with him. In addition, there appears to be a lack of support for " $\mathrm{H}$ " when he experiences difficulties. On the other hand " $\mathrm{H}$ " has a lack of self-esteem, insecurity, low adversity, and despair with activities related to the obstacles he experience. Sometimes, when $\mathrm{H}$ gives up on assignments, some friends laugh. This is certainly not good for his psychological development, and also the class climate.

$\mathrm{H}$ aachievements in class may not be the optimal ability that he can show when he has obstacles. Moreover, the obstacles of experience are not only physical, but also emotional and social related to the acceptance of classmates. Against this background, the researcher is interested in conducting research related to this problem by providing a learning model that can accommodate the needs of all students in the inclusion class namely the model equality dynamic learning.

Equality Dynamic Learning which can be abbreviated with EDL implies that a dynamic learning model providing equal learning rights opportunities to the learner. Dynamic learning is a series of learning activities designed to enable a meaningful learning process for students. The implication is that learning as a process must be designed, developed and managed creatively, dynamically, by applying a multi-level approach to creating an atmosphere and learning process that is conducive for students.

The equality dynamic learning model conceptualizes "dynamic learning that creates equal rights in learning", meaning that learning activities are designed in such a way that takes into account the diversity that is owned by students (students with special and regular needs) and accommodates all these needs in learning activities so that all students in the class have meaningful learning.

Learning that creates equal rights is certainly synergized with the goal of inclusive education. Currently, inclusive education has developed rapidly in several major cities throughout Indonesia, as well as in Higher Education. With the inclusion of students with special needs in tertiary institution, the model of inclusive education requires the innovative learning model that is able to develop as the needs of the students.

General description of EDL is explained in the chart below:

Table 1. General Description of Model Implementation EDL

\begin{tabular}{|c|c|c|}
\hline $\begin{array}{c}\text { 1Learning } \\
\text { Planning in EDL }\end{array}$ & $\begin{array}{l}\text { 2Learning } \\
\text { Process in EDL }\end{array}$ & $\begin{array}{l}\text { 3. Evaluation of } \\
\text { Learning in EDL }\end{array}$ \\
\hline $\begin{array}{l}\text { - Need analysis } \\
\text { - Creating a } \\
\text { climate of } \\
\text { awareness } \\
\text { - Learning } \\
\text { program }\end{array}$ & $\begin{array}{l}\text { - Deep learning } \\
\text { - Problem } \\
\text { based learning } \\
\text { - Project based } \\
\text { learning }\end{array}$ & $\begin{array}{l}\text { - Test } \\
\text { - Non test } \\
\text { - Process } \\
\text { analysis } \\
\text { - Product }\end{array}$ \\
\hline
\end{tabular}

Based on the chart above, the EDL model includes three main points. First, Planning, it is about analysis of the need and raising a good climate in the classroom. We did some analysis of the needs of students and lecturer with questioners in the first session of the subject. Then, we were creating disability awareness activities at the beginning of the learning. When using this model, students must be in random groups, actively involved, and have a shared 
commitment to respect each other and accept diversity in the classroom.

Second, there is the learning process in the EDL model. We combine deep learning, Problem-based learning, and Project-based learning. So, after students understand the theories and concepts, then they find problems and issues related to the theory or concept, so the final action is what products they create based on the problems of the issues they found.

Then, the third stage in the EDL model is the evaluation of learning given to students in the form of:

1) The test related to concepts and theories given in writing to students.

2) Non-tests related to student behavior and attitudes related to the diversity of peers during the learning process (relating to ethics and caring for others)

3) Analysis of the process related to the presence of students in attending lectures, completion of assignments to the creation of products, student contributions during the discussion, and the process of student presentations.

4) Products related to solutions created by groups of students in solving problems found that are considered related to the suitability of the product with the description of the problem, the creativity of students in creating, modifying or innovating a solution, here in after referred is created or developed product.

Beside considering inclusive education, the equality dynamic learning model also considers the needs of students with special needs which are examined from several learning principles of individuals with special needs, namely: real, dynamic programs (a dynamic program), equal opportunities (equality of opportunity), and cooperation (cooperative).

Therefore, the EDL model is defined as a model related to the needs of inclusive class where students' abilities and problems are heterogeneous so that they require dynamic learning in order to accommodate each student's learning system, and the EDL model provides a learning process and experience that respects togetherness so that it is expected that every student both regular students and students

Cite this as:

Yulvia Sani, Ossy Firstanti Wardany. The Effectiveness of the Equality Dynamic Learning Model in Increasing Disability Awareness of Students in Inclusion Classes.Indonesian Journal of Disability Studies (IJDS).2020: Vol. 7(1): PP 28-39. with special needs can share experiences, share curiosity, foster a climate of awareness so that learning has meaning.

\section{Research Methodology}

The research method is a procedure and work steps used in research activities regularly and systematically, starting from the planning stage, data collection, data processing to the conclusion stage (Sutedi, 2009: 53). This research used the Quasi-Experimental Design research method. Quasi experimental design is a study carried out in the absence of a control class (Arikunto: 2002). The experimental design used the One Group Pre-post-test. The design of this study was measured using pre tests conducted before being treated and post tests conducted after being given treatment.

When implementing this method, research is carried out on one class and with the pre-test and post-test would be able to show differences before and after treatment is given. The aim of the researchers using this method is to determine the effectiveness of the equality dynamic learning model in increasing the disability awareness of students in inclusive classes. This study involved 19 students in third semesters, 1 student experienced physical disabilities, and 18 regulars' students.

In this study, the students were given one initial test measurement aimed to know the level of disability awareness of students before being given treatment, after being given treatment students were given further measurements in the form of a final test to measure the level of disability awareness of students after receiving treatment.

The research design is as follows:

\begin{tabular}{|c|l|c|}
\hline O1 & \multicolumn{1}{|c|}{$\mathrm{X}$} & $\mathrm{O} 2$ \\
\hline Caption: & \\
O1 & : pre test \\
$\mathrm{X}$ & : treatment & \\
O2 & : post-test
\end{tabular}

Data collection techniques in this quasiexperimental study used a disability awareness scale and in the form of sociometry. The students were given one initial test measurement aimed to know the level of disability awareness of students before and 
after the intervention. We used disability awareness rating scale to measure the effectiveness. The rating scale instrument for students was adapted and developed from the Getskow \& Konczal awareness instruments (1996) and "Disability Awareness Checklist" from McGrail \& Rieger (2013). The aspects assessed are knowledge, attitudes, and behaviour. In the aspect of knowledge, there is the concept of $\mathrm{ABK}$ and general knowledge about disabilities, Characteristics of some kind of disabilities, and the needs of disabilities. In the aspect of attitude, there is a perception and acceptance of people with disabilities. Next on the behavioural aspect is the interaction and friendship with disabilities. There are 77 statements, both favorable and unfavourable statements. The rating scale starts from strongly-agree, agree, disagree, and strongly disagree.

Data processing were done by looking at the 'disability awareness score. We get the results from comparing disability awareness scores before and after the model is applied.

The procedure of this research starts from the preparation consisting of: needs analysis, preparation of the draft equality dynamic learning model, conducting focus group discussions to validate the draft of the model, making semester program design, making disability awareness scale questionnaires for pre-test and post-test. Followed by the implementation of a series of activities is a learning process in this case in the Assessment of Children with Special Needs subject which is conducted 8 times using the equality dynamic learning model. After 8 meetings or treatments are given, then the next level of disability awareness is measured (posttest) through a questionnaire.

\section{Result and Discussion}

Before the treatment being given, pre-test was given to measure disability awareness, after obtaining pre-test data, researchers gave treatment to change the results of pre-test that had been pressed through 8 times using the equality dynamic learning model, then students are measured again at their disability awareness called post-test .

\subsection{Pre Test Results}

The measurement of the level of disability awareness was carried out on 19 students (18 regular students and 1 student with special needs). The students filled out a scale of disability awareness that sought to express their awareness of children with special needs from aspects of knowledge, attitudes, and behavior. Therefore, it was expected to illustrate how their awareness and acceptance of students with special needs.

The pre-test and post-test disability awareness results of the students are presented as follows on the Table 2 .

Table 2. Pre test results (the disability awareness scores)

\begin{tabular}{|l|l|l|}
\hline CATEGORY & amount & percentage \\
\hline Very Low & - & \\
\hline Low & - & \\
\hline Medium & 12 & $63 \%$ \\
\hline High & 7 & $37 \%$ \\
\hline Very High & - & \\
\hline
\end{tabular}

Beside using a questionnaire to reveal the level of disability awareness of students, researchers also use sociometry to strengthen the results of the questionnaire.

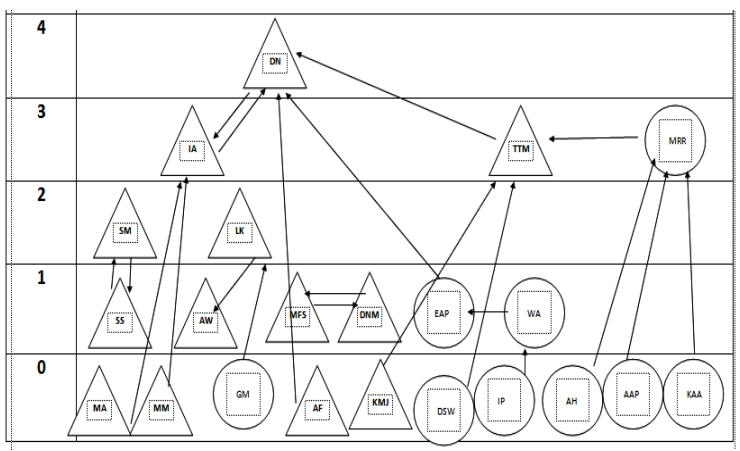

Caption:

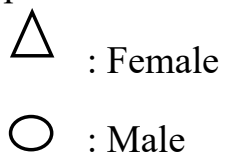

Fig 1. Sociometry results of students who are liked and wanted to be invited to groups 
The results of sociometry above show that " $\mathrm{H}$ " was not chosen by his all classmates to be invited groups work.

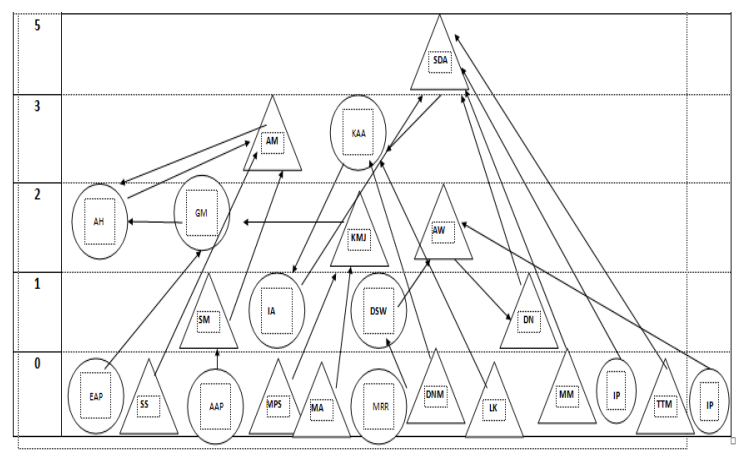

Fig 2. Sociometry results of students who are the least close and undesirable for groups

The results of sociometry in Figure 2 explain there are some friends who do not want to work in groups with $\mathrm{H}$. Based on preliminary data findings; researchers can say that in general, students' disability awareness scores are indeed not so low. However, if examined in more detail, it is found that there are tendencies of some students to avoid interacting and dealing with individuals with special needs. This, of course, is of concern to researchers because later they will intersect and interact with students with special needs. So that attitudes and behavioral tendencies like that must be faded.

\subsection{Post Test Results}

After being given the treatments, the results of the post-test disability awareness of students in the inclusion class were as follows on the Table 3 and Table 4.

Table 3. Disability Post Test Results of Student's Disability Awareness

\begin{tabular}{|c|c|c|}
\hline \multirow{2}{*}{ No } & \multicolumn{2}{|c|}{ Post Test } \\
\cline { 2 - 3 } & score & Category \\
\hline 1 & 278 & Very High \\
\hline 2 & 254 & Very High \\
\hline 3 & 273 & Very High \\
\hline 4 & 288 & Very High \\
\hline 5 & 257 & Very High \\
\hline 6 & 262 & Very High \\
\hline 7 & 307 & Very High \\
\hline 8 & 271 & Very High \\
\hline
\end{tabular}

\begin{tabular}{|c|c|c|}
\hline 9 & 278 & Very High \\
\hline 10 & 281 & Very High \\
\hline 11 & 279 & Very High \\
\hline 12 & 259 & Very High \\
\hline 13 & 266 & Very High \\
\hline 14 & 278 & Very High \\
\hline 15 & 238 & High \\
\hline 16 & 237 & High \\
\hline 17 & 241 & High \\
\hline 18 & 253 & Very High \\
\hline 19 & 268 & Very High \\
\hline
\end{tabular}

Table 4. Summary of Disability Post Test Results of Student Awareness

\begin{tabular}{|l|l|l|}
\hline CATEGORY & amount & precentage \\
\hline Vey Low & & \\
\hline Low & & \\
\hline Medium & & \\
\hline High & 3 & $16 \%$ \\
\hline Very High & 16 & $84 \%$ \\
\hline
\end{tabular}

After the treatment was given, it clearly showed that there was an increasing significantly in the disability awareness of students. As we can see from as categorize medium at the pre-test were $63 \%$, and the high category was at $37 \%$.Then, In the post-test, the students' disability awareness ability is in the high and very high categories. Strengthening these results, researchers conducted the calculations by using Wilcoxon with the following results:

Table 5. Wilcoxon results

\begin{tabular}{|ll|r|r|r|}
\hline \multicolumn{5}{|c|}{ Ranks } \\
\hline & & \multicolumn{1}{|c|}{ N } & Mean Rank & Sum of Ranks \\
\hline Post test - pre test & Negative Ranks & $0^{a}$ &, 00 &, 00 \\
& Positive Ranks & 19 & 10,00 & 190,00 \\
& Ties & 0 & & \\
\cline { 2 - 5 } & Total & 19 & & \\
\hline
\end{tabular}

a. post test < pre test

b. post test > pre test

c. post test $=$ pre test

The final results of the Wilcoxon calculation are presented in Table 6 .

Table 6. Final results of Wilcoxon in calculating students' disability awareness

Cite this as:

Yulvia Sani, Ossy Firstanti Wardany. The Effectiveness of the Equality Dynamic Learning Model in Increasing Disability Awareness of Students in Inclusion Classes.Indonesian Journal of Disability Studies (IJDS).2020: Vol. 7(1): PP 28-39. 


\begin{tabular}{|l|r|}
\hline \multicolumn{2}{|c|}{ Test Statistics $^{\mathbf{a}}$} \\
\hline $\mathrm{Z}$ & \multicolumn{1}{|c|}{ Pre test- Post Test $^{-3,824 \mathrm{~b}}$} \\
$\begin{array}{l}\text { Asymp. Sig. (2- } \\
\text { tailed) }\end{array}$ &, 000 \\
\hline \begin{tabular}{l} 
a. Wilcoxon Signed Ranks Test \\
\hline b. Based on negative ranks.
\end{tabular} \\
\hline
\end{tabular}

\section{Hypothesis}

Ho: The EDL model is not effective in increasing student disability awareness

Ha: The EDL model effectively increases student disability awareness

\section{Decision-making}

- If the probability is $<0.05$, then Ho is accepted

- If the probability is $<0.05$, then Ho is rejected

It can be seen that in the asymp sig (2-tailed) column for testing the 2 sides is 0,000 . Because the case is a one-tailed test, the probability becomes $0,000 / 2=0,000$. Here the probability is below to 0.05 , so Ho is rejected and $\mathrm{Ha}$ is accepted.

\subsection{Discussion}

It can be found that EDL is effective in increasing disability awareness. At the beginning of the learning process, there are activities that create a climate of acceptance of diversity and provide more knowledge about disability. It was influential on the subsequent knowledge and their attitude in class. The level of awareness of regular students which is still lacking can be due to the lack of knowledge about disability (McGail \& Rieger, 2013). Thus providing knowledge and creating a climate of acceptance is proven to raise disability awareness in this study.

Based on the results of research and increased acceptance to the " $\mathrm{H}$ " while studying in class, it is indicating that growing disability awareness is very important. This is in accordance with Liberman \& Houston-Wilson (2002) which states that there are several benefits to be gained when raising disability awareness, namely, Increasing student acceptance of classmates with special needs; Improving socialization among all students and

Cite this as:

Yulvia Sani, Ossy Firstanti Wardany. The Effectiveness of the Equality Dynamic Learning Model in Increasing Disability Awareness of Students in Inclusion Classes.Indonesian Journal of Disability Studies (IJDS).2020: Vol. 7(1): PP 28-39.

also improving students' perceptions of disabilities. Getskow \& Konczal (1996) suggested that put disability awareness into the curriculum is one way to increase classroom acceptance of disability and diversity. This is evident in the implementation of The EDL Model, by including activities that provide knowledge about disability, involving students with special needs in the classroom, raising acceptance and respect for every student and being grateful, the acceptance other students to " $\mathrm{H}$ " increased.

\section{Conclusion}

Equality Dynamic Learning which impliedd that a dynamic learning model had provided such an equal learning rights opportunity to the learner. The results of the application of this model provided many conveniences and benefits for lecturers or students in the learning process. The benefits and ease felt by the lecturers were knowing the learning needs of each student in order to facilitate the provision of understanding material to students, while the ease and benefits felt by students were the loss of homogeneous learning groups which was only useful for certain students. The limitation of this study is that it only tests one inclusion class with students with special needs (physical impairment). The EDL model has not been applied to inclusive classes with more types of special needs for students. Thus, further development and research is needed regarding the effectiveness of this model.

\section{Suggestion}

a. For lecturers supporting the assessment of children with special needs:

Learning planning in the first stage. At this stage, a needs of assessment was conducted to identify learning needs and identify problems in the inclusive class, creating a climate of awareness in order to avoid inequality in students. The learning implementation phase also had the implementation stages, namely deep learning, problem based learning and project based learning. The last stage was the evaluation of learning in the EDL model. Evaluation was done in order to see the extent to which students' understanding of the 
concepts of the courses taught and see the implementation of climate awareness created.

b. For students who take the Children Assessment Special Needs course:

Students can express how their learning needs are. So that in the learning process they can accept the material provided easily. With the climate of awareness, students feel the loss of discrimination at the time of group division, where previously those who had good abilities would form their fellow groups. Therefore, those who have ordinary abilities and children with special needs were hardly accepted in groups.

\section{References}

Amri, S., \& Iif, K. A. (2010). Proses Pembelajaran Kreatif dan Inovatif Dalam Kelas: Metode, Landasan Teoritis-Praktis dan Penerapannya. Jakarta: $\quad P T . \quad$ Prestasi Pustakaraya.

Arifin, Zainal. (2011). Penelitian Pendidikan. Bandung: PT Remaja Rosdakarya.

Arikunto, S. (2002). Prosedur Penelitian Suatu Pendekatan Praktek, Cet. Ke-12. Jakarta. Rineka Cipta.

Baharuddin, B., \& Wahyuni, E. N. (2008). Teori belajar dan pembelajaran.

Budiningsih, C, Asri. (2012). Belajar dan pembelajaran.Jakarta:PT Rineka Cipta.

De Boer, A., Pijl, S. J., \& Minnaert, A. (2010). Attitudes of parents towards inclusive education: A review of the literature. European Journal of Special Needs Education, 25(2), 165-181.

Bukvic, Z. (2014). Teachers competency for inclusive education. The European Journal of Social \& Behavioural Sciences, 11(4), 1585.

Daryanto. (2010). Media Pembelajaran Peranannya Sangat Penting Dalam Mencapai Tujuan Pembelajaran. Cetakan kedua. Cetakan kelima. Bandung: PT. Sarana Nurani Sejahtera.

Djamarah, Syaiful Bahri., Zain, Aswan . (2010). Strategi Belajar Mengajar. Cetakan keempat. Jakarta: Rineka Cipta.

Falvey Mary,A. (1986) Community Based Curriculum Instruction Strategies For
StudentWith Severe Handicaps, London: Brooks Publishing Company

Getskow,V \& Konczal,D. (1996). Kids With Special Needs: Information and activities to promote awareness and understanding. California: The Learning Works.

Huda, Miftahul. (2013). ModelmodelPengajaran dan Pembelajaran. Yogyakarta: PT Pustaka Pelajar.

Lieberman, L. J., \& Houston-Wilson, C. (2009). Strategies for inclusion. Champaign, Illinois: Human Kinetics.

Mulyasa, E., (2007). Standar Kompetensi dan Sertifikasi Guru. Bandung: PT Remaja Rosdakarya.

McGail,E. \& Rieger,A. (2013). Increasing Disability Awareness through Comics Literature. Electronic Journal for Inclusive Education Vol 3 No 1. Art 5 1-20

Kirkpatrick, D. L. (2001). Evaluating training programs, the four levels. San Diego.

Kolb, D. A., Boyatzir, R. E., \& Mainemelis, C. (1999). Eperriental Learning Teory.Perspective on cognitive, learning, and thinking styles.

McLoughlin,James,A. \& Lewis, Rena,B. (1986). Assessing Special Students (2nd) USA: MerrilPublishing Company

Nasution. (2008). Berbagai Pendekatan dalam Proses Belajar \& Mengajar.Cetakan keduabelas.Jakarta : Bumi Aksara.

Rochyadi \&Alimin, Z. (2003) Pengembangan Program Individual Bagi Anak Tunagrahita, Jakarta: Depdiknas

Sarwono, Jonathan. (2006). Metode Penelitian kuantitatif\&kualitatif .Edisi kesatu.Yogyakarta : Graha Ilmu.

Subyantoro, dkk. (2011). Paedagogik Jurnal Pendidikan Dasar dan Menengah. Volume 5. Semarang: Laboratorium dan Baca Tulis Universitas Semarang.

Sudjana, Nana. (2010). Penilaian hasil Proses Belajar Mengajar. Bandung: PT Remaja Rosdakarya.

Cite this as:

Yulvia Sani, Ossy Firstanti Wardany. The Effectiveness of the Equality Dynamic Learning Model in Increasing Disability Awareness of Students in Inclusion Classes.Indonesian Journal of Disability Studies (IJDS).2020: Vol. 7(1): PP 28-39. 
IJDS 2020; Vol.7 No. 1, May 2020, pp. 28-39

ISSN: $2355-2158$ e-ISSN: 2654-4148

DOI: dx.doi.org/10.21776/ub.ijds.2019.007.01.3

Suprijono, Agus. (2012). Cooperative Learning Teori \& Aplikasi Paikem. Cetakan Ketujuh. Yogyakarta: Pustaka Pelajar.

Soendari, T., (1996), Penerapan Program Individuali sasi dalam Pengajaran Berhitung bagiAnak Luar Biasa, (Makalah disajikan dalam P2M pada Guru -guru SLB diKodya Bandung).

Yusuf, M.dkk., (2005). Asesmen Perkembangan pada Anak Tunagrahita, Jakarta: Departemen Pendidikan Nasional

Zaini, Hisyam., Munthe, Bermawy., Aryani, Ayu Sekar. (2008). Strategi Pembelajaran Aktif. Yogyakarta: Center for Teaching Staf Development (CTSD) UIN Sunan Kalijaga Yogyakarta.

Cite this as:

Yulvia Sani, Ossy Firstanti Wardany. The Effectiveness of the Equality Dynamic Learning Model in Increasing Disability Awareness of Students in Inclusion Classes.Indonesian Journal of Disability Studies (IJDS).2020: Vol. 7(1): PP 28-39. 
IJDS 2020; Vol.7 No. 1, May 2020, pp. 28-39

ISSN: $2355-2158$ e-ISSN: 2654-4148

DOI: dx.doi.org/10.21776/ub.ijds.2019.007.01.3

Appendix 1. Disability Awareness Rating Scale.

a. Matriks Instrumen Kesadaran terhadap ABK

\begin{tabular}{|c|c|c|c|c|}
\hline Variabel & Definisi Operasional & $\begin{array}{c}\text { Aspek yang } \\
\text { dinilai }\end{array}$ & indikator & Teknik \\
\hline \multirow[t]{3}{*}{$\begin{array}{l}\text { Kesadaran } \\
\text { terhadap ABK } \\
\text { (disability } \\
\text { awareness) }\end{array}$} & \multirow{3}{*}{$\begin{array}{l}\text { Kesadaran terhadap anak } \\
\text { berkebutuhan khusus ialah } \\
\text { keadaan ketika seseorang } \\
\text { memiliki pengetahuan dan } \\
\text { pemahaman yang cukup } \\
\text { mengenai konsep ABK } \\
\text { sehingga dapat dan mene-rima } \\
\text { kehadiran ABK di lingkungan } \\
\text { mereka berada. }\end{array}$} & $\begin{array}{l}\text { Pengeta- } \\
\text { huan }\end{array}$ & $\begin{array}{ll}\text { 1. } & \text { Pengertian dan } \\
& \text { konsep ABK } \\
\text { 2. } & \text { Karakteristik } \\
\text { 3. } & \text { Kebutuhan ABK }\end{array}$ & \multirow[t]{3}{*}{ Kueisioner } \\
\hline & & Sikap & $\begin{array}{ll}\text { 1. Persepsi terhadap } \\
\text { ABK } \\
\text { 2. } \\
\text { Penerimaan } \\
\text { terhadap ABK } \\
\end{array}$ & \\
\hline & & Perilaku & $\begin{array}{lll}\text { a. } & \text { Interaksi dan } \\
& \text { pertemanan } & \\
& \text { dengan ABK } & \end{array}$ & \\
\hline
\end{tabular}

Catatan :

Instrumen kuesioner untuk siswa diadaptasi dan dikembangkan dari instrumen kesadaran Getskow \&

Konczal (1996) dan Disability Awareness Checklist dari McGrail \& Rieger (2013).

b. Rekaan Teoritis : Kesadaran terhadap ABK pada Siswa Reguler

Ket : (f) $=$ Favorable $($ uf $)=$ unfavorable

\begin{tabular}{|c|c|c|}
\hline $\begin{array}{c}\text { Aspek yang } \\
\text { dinilai }\end{array}$ & indikator & Penyataan \\
\hline \multirow[t]{2}{*}{ Pengetahuan } & $\begin{array}{l}\text { Konsep ABK dan } \\
\text { pengetahuan umum } \\
\text { soal ABK }\end{array}$ & $\begin{array}{l}\text { 1. Tidak semua disabilitas terlihat secara fisik (F) } \\
\text { 2. } 13 \text { Desember merupakan hari disabilitas nasional (UF) } \\
\text { 3. Ada disabilitas yang tidak terlihat oleh mata (F) } \\
\text { 4. Tidak semua ABK lahir dengan kebutuhan khususnya } \\
\text { (F) } \\
\text { 5. Beberapa anak menjadi berkebutuhan khusus di usia } \\
\text { balita (F) } \\
\text { 6. Saya memahami semua konsep ABK menurut IDEA (F) } \\
\text { 7. Paralympic adalah olahraga untuk orang berkebutuhan } \\
\text { khusus (F) }\end{array}$ \\
\hline & Karakteristik ABK & $\begin{array}{l}\text { 8. Anak dengan hambatan motorik pasti memakai kursi } \\
\text { roda/kruk/tongkat (UF) } \\
\text { 9. Beberapa anak autis merasa tidak nyaman dengan suara } \\
\text { atau keramaian (F) } \\
\text { 10. Semua anak berkebutuhan khusus pasti pemalu (UF) } \\
\text { 11. Semua jenis anak berkebutuhan khusus berbeda secara } \\
\text { fisik dari teman yang lain (UF) } \\
\text { 12. Anak berkesulitan belajar mengalami masalah saat } \\
\text { belajar di kelas (F) } \\
\text { 13. Anak Asperger dapat berbicara seperti anak lain (F) } \\
\text { 14. Anak berkesulitan belajar pasti memiliki IQ di bawah } \\
\text { normal (UF) } \\
\text { 15. Autis bukan penyakit dan salah asuhan (F) } \\
\text { 16. Semua anak tunanetra pasti melihat dunia gelap gulita } \\
\text { (UF) } \\
\text { 17. Semua tunanetra pasti tidak bisa melihat sejak lahir } \\
\text { (UF) }\end{array}$ \\
\hline
\end{tabular}

Cite this as:

Yulvia Sani, Ossy Firstanti Wardany. The Effectiveness of the Equality Dynamic Learning Model in Increasing Disability Awareness of Students in Inclusion Classes.Indonesian Journal of Disability Studies (IJDS).2020: Vol. 7(1): PP 28-39. 


\begin{tabular}{|c|c|c|}
\hline & & $\begin{array}{l}\text { 18. Echolalia dapat dihilangkan dengan modifikasi dan } \\
\text { terapi perilaku (F) } \\
\text { 19. Anak dengan HOH masih punya sisa pendengaran (F) } \\
\text { 20. Masalah belajar pada anak kesulitan belajar sama (UF) }\end{array}$ \\
\hline & Kebutuhan ABK & $\begin{array}{l}\text { 21. Anak tunanetra (buta) menulis dengan alat bernama } \\
\text { riglet dan stylus (F) } \\
\text { 22. Beberapa anak berkebutuhan khusus membutuhkan } \\
\text { guru pembimbing khusus (F) } \\
\text { 23. Anak dengan hambatan fisik kadang membutuhkan } \\
\text { kursi roda atau kruk (F) } \\
\text { 24. Beberapa anak membutuhkan waktu yang lebih lama } \\
\text { ketika mengerjakan tugas (F) } \\
\text { 25. Aksesibilitas tidak hanya berkaitan dengan bangunan, } \\
\text { tetapi juga pembelajaran (F) } \\
\text { 26. ABK tidak hanya butuh aksesibilitas tetapi juga } \\
\text { penerimaan masyarakat (F) } \\
\text { 27. ABK butuh dihargai seperti anak lain (F) } \\
\text { 28. ABK tidak butuh dihargai, mereka hanya perlu } \\
\text { dikasihani (UF }\end{array}$ \\
\hline \multirow[t]{2}{*}{ Sikap } & Persepsi terhadap ABK & $\begin{array}{l}\text { 29. Anak berkebutuhan khusus tidak suka berteman (UF) } \\
\text { 30. Anak tunanetra (buta) tidak bisa membaca (UF) } \\
\text { 31. Anak berkursi roda tidak bisa bermain basket atau } \\
\text { bulutangkis (UF) } \\
\text { 32. Anak-anak berkebutuhan khusus tidak bisa apa-apa } \\
\text { (UF) } \\
\text { 33. Anak berkebutuhan khusus juga bisa pintar dan } \\
\text { berprestasi seperti anak lain (F) } \\
\text { 34. Anak berkebutuhan khusus juga bisa naik sepeda, } \\
\text { bermain bola dan berenang (F) } \\
\text { 35. Anak berkebutuhan khusus seharusnya berkampus } \\
\text { seperti anak lain (F) } \\
\text { 36. Anak berkebutuhan khusus bisa jadi teman yang } \\
\text { menyenangkan (F) } \\
\text { 37. Anak berkebutuhan khusus pasti punya potensi yang } \\
\text { sama untuk berprestasi (F) } \\
\text { 38. Teman yang berkebutuhan khusus pun ingin mandiri (F) } \\
\text { 39. Teman berkebutuhan khusus suka dikasihani (UF) } \\
\text { 40. Orang berkebutuhan khusus selalu membutuhkan } \\
\text { bantuan setip hari (UF) }\end{array}$ \\
\hline & $\begin{array}{l}\text { Penerimaan terhadap } \\
\text { ABK }\end{array}$ & $\begin{array}{l}\text { 41. Anak yang buta, tuli, autis, atau berkursi roda boleh } \\
\text { kuliah di kampusku (F) } \\
\text { 42. Kita harus menerima kelebihan dan kekurangan teman } \\
\text { kita (F) } \\
\text { 43. Saya tidak suka dengan penyebutan idiot, gila, atau } \\
\text { cacat (F) } \\
\text { 44. Tidak masalah kita memanggil teman dengan sebutan } \\
\text { autis, cacat, pincang atau idiot karena memang begitu } \\
\text { adanya (UF) } \\
\text { 45. Kampus hanya untuk anak yang normal saja (UF) } \\
\text { 46. Saya akan menjauhi teman yang autis (UF) } \\
\text { 47. Anak difabel sebaiknya sekolah di sekolah khusus saja } \\
\text { dan tidak perlu masuk inklusi (UF) } \\
\text { 48. Saya agak malas kalau di kampus saya ada mahasiswa } \\
\text { berkebutuhan khusus (UF) }\end{array}$ \\
\hline
\end{tabular}

Cite this as: 
IJDS 2020; Vol.7 No. 1, May 2020, pp. 28-39

ISSN: 2355 - 2158 e-ISSN: $2654-4148$

DOI: dx.doi.org/10.21776/ub.ijds.2019.007.01.3

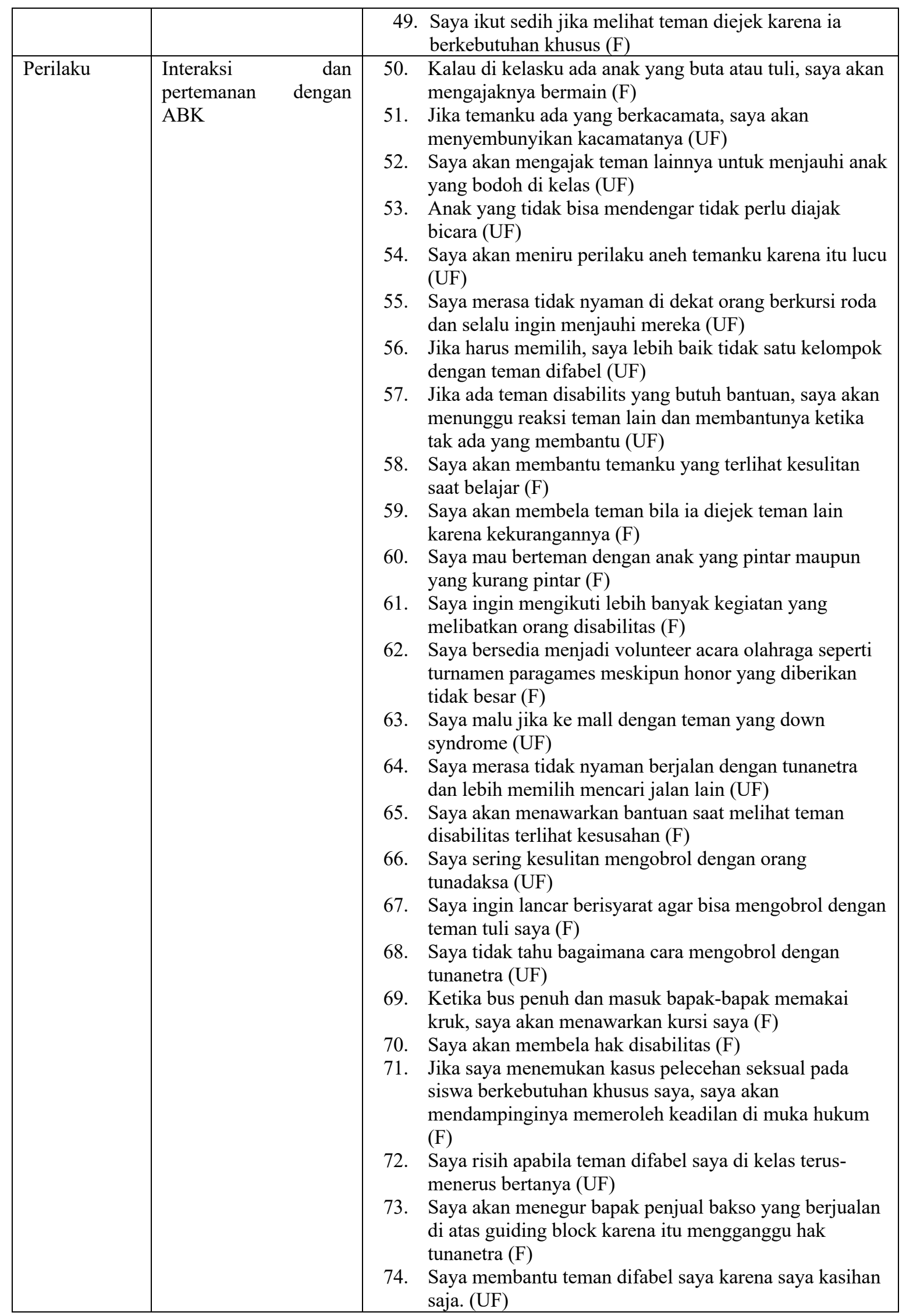

Cite this as:

Yulvia Sani, Ossy Firstanti Wardany. The Effectiveness of the Equality Dynamic Learning Model in Increasing Disability Awareness of Students in Inclusion Classes.Indonesian Journal of Disability Studies (IJDS).2020: Vol. 7(1): PP 28-39. 


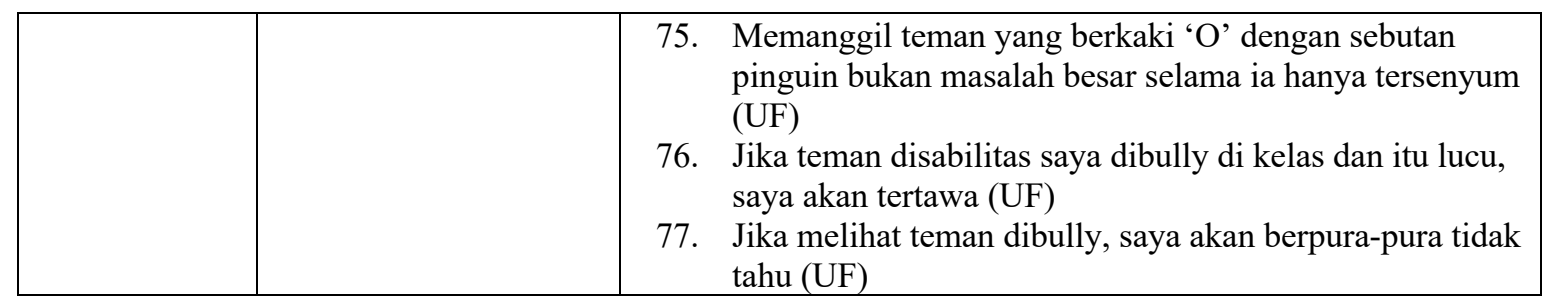

\section{Kriteria Penilaian}

Pada pernyataan favorable, skor jawaban sangat setuju (4), Setuju (3), Tidak setuju (2) dan jawaban Sangat tidak setuju (1)

Pada penyataan unfavorable, Sangat setuju (1), Setuju (2), Tidak setuju (3) dan jawaban Sangat tidak setuju (4)

\section{Kategori skor}

\begin{tabular}{|c|c|}
\hline Sangat Rendah & $\mathrm{X}<134,75$ \\
\hline Rendah & $134,75<\mathrm{X} \leq 173,25$ \\
\hline Sedang & $17325<\mathrm{X} \leq 211,75$ \\
\hline Tinggi & $211,75<\mathrm{X} \leq 250,25$ \\
\hline Sangat Tinggi & $\mathrm{X}>250,25$ \\
\hline
\end{tabular}

